\title{
Antifungal and antibacterial activities of Petroselinum crispum essential oil
}

\author{
G.A. Linde ${ }^{1}$, Z.C. Gazim ${ }^{1}$, B.K. Cardoso ${ }^{1}$, L.F. Jorge ${ }^{1}$, V. Teševič ${ }^{2}$, \\ J. Glamoćlija ${ }^{3}$, M. Soković ${ }^{3}$ and N.B. Colauto ${ }^{1}$ \\ ${ }^{1}$ Programa de Pós-Graduação em Biotecnologia Aplicada à Agricultura, \\ Universidade Paranaense, Umuarama, PR, Brasil \\ ${ }^{2}$ School of Chemistry, University of Belgrade, Belgrade, Serbia \\ ${ }^{3}$ Mycological Laboratory, Institute for Biological Research, Siniša Stanković, \\ University of Belgrade, Belgrade, Serbia \\ Corresponding author: N.B. Colauto \\ E-mail: nbc@unipar.br
}

Genet. Mol. Res. 15 (3): gmr.15038538

Received February 11, 2016

Accepted March 21, 2016

Published July 29, 2016

DOI http://dx.doi.org/10.4238/gmr.15038538

Copyright (C) 2016 The Authors. This is an open-access article distributed under the terms of the Creative Commons Attribution ShareAlike (CC BY-SA) 4.0 License.

\begin{abstract}
Parsley [Petroselinum crispum (Mill.) Fuss] is regarded as an aromatic, culinary, and medicinal plant and is used in the cosmetic, food, and pharmaceutical industries. However, few studies with conflicting results have been conducted on the antimicrobial activity of parsley essential oil. In addition, there have been no reports of essential oil obtained from parsley aerial parts, except seeds, as an alternative natural antimicrobial agent. Also, microorganism resistance is still a challenge for health and food production. Based on the demand for natural products to control microorganisms, and the reevaluation of potential medicinal plants for controlling diseases, the objective of this study was to determine the chemical composition and antibacterial and antifungal activities of parsley essential oil against foodborne diseases and opportunistic pathogens. Seven bacteria and
\end{abstract}


eight fungi were tested. The essential oil major compounds were apiol, myristicin, and $\beta$-phellandrene. Parsley essential oil had bacteriostatic activity against all tested bacteria, mainly Staphylococcus aureus, Listeria monocytogenes, and Salmonella enterica, at similar or lower concentrations than at least one of the controls, and bactericidal activity against all tested bacteria, mainly $S$. aureus, at similar or lower concentrations than at least one of the controls. This essential oil also had fungistatic activity against all tested fungi, mainly, Penicillium ochrochloron and Trichoderma viride, at lower concentrations than the ketoconazole control and fungicidal activity against all tested fungi at higher concentrations than the controls. Parsley is used in cooking and medicine, and its essential oil is an effective antimicrobial agent.

Key words: Chemical composition; Antifungal activity; Parsley; Antibacterial activity; Petroselinum sativum; Essential oil

\section{INTRODUCTION}

Petroselinum crispum (Mill.) Fuss, also referred to as Petroselinum sativum Hoffm., Petroselinum vulgare Lagasca, Petroselinum crispum (Mill.) Nyman ex A.W. Hill, Apium petroselinum L., Carum petroselinum (L.) Benth., Hook. f., and Petroselinum hortense Hoffm., belongs to the Umbelliferae family, and is commonly known as parsley. Parsley is regarded as an aromatic, culinary, and medicinal plant and is used in the cosmetic, food, and pharmaceutical industries. However, few studies with conflicting results have been conducted on the antimicrobial activity of parsley essential oil (Gutierrez et al., 2008; Viuda-Martos et al., 2011; Teixeira et al., 2013).

In previous studies in our laboratory, parsley essential oil showed antimicrobial activity against several bacteria such as Escherichia coli, Listeria monocytogenes, Salmonella enterica, Enterobacter cloacae, and Pseudomonas aeruginosa among others and some fungi (Linde GA, Gazim ZC and Colauto NB, unpublished results). However, it has been reported that essential oil from parsley aerial parts does not present antibacterial activity against these bacteria (Gutierrez et al., 2008; Teixeira et al., 2013). P. aeruginosa is an important opportunistic pathogen that causes diseases in animals (Bjarnsholt et al., 2010) and plants (Iglewski, 1996) as well as other bacteria cited above (Addis and Sisay, 2015). In addition, the Aspergillus and Penicillium genera are common causal agents of foodborne diseases and food spoilage that increase the cost of food production and healthcare throughout the world (Mead et al., 1999). In addition, the Trichoderma genus is the most common contaminant in mushroom cultivation and causes enormous economic losses around the world (Burt, 2004). However, there have been no reports of essential oil obtained from parsley aerial parts, except seeds, as an alternative natural product to control most of these fungi.

Furthermore, microorganism resistance is a challenge for health and food production, and the search for alternative natural antimicrobial agents continues (Ding et al., 2010; Soković et al., 2014). Synthetic fungicides, for instance, are generally effective and inexpensive, but it has been suggested that they leave residual toxicity that may have carcinogenic and teratogenic side effects (McCarroll et al., 2002). Moreover, most of the synthetic fungicides have been restricted or banned in several countries since the early 1960s (Glamočlija et al., 2011).

Genetics and Molecular Research 15 (3): gmr.15038538 
Based on the demand for natural products to control microorganisms, and the re-evaluation of potential medicinal plants for controlling diseases, the objective of this study was to determine the chemical composition and antibacterial and antifungal activities of parsley essential oil against foodborne diseases and opportunistic pathogens.

\section{MATERIAL AND METHODS}

\section{Essential oil}

P. crispum was deposited at Universidade Paranaense Herbarium, voucher specimen 2215. It was cultivated in a space of $0.3 \times 0.4 \mathrm{~m}$ located at coordinates $23^{\circ} 46.225^{\prime} \mathrm{S}$ and $53^{\circ} 16.730^{\prime} \mathrm{WO}$ and an altitude of $391 \mathrm{~m}$. Parsley aerial parts (leaves, stems, and flowers without seeds) were harvested in the morning, immediately after early dew evaporation. Essential oil was obtained from fresh material $(1.5 \times 1.5 \mathrm{~mm}$ cut $)$ by hydro distillation for $2 \mathrm{~h}$ in a Clevenger apparatus. After distillation, the essential oil was filtered through an anhydrous $\mathrm{Na}_{2} \mathrm{SO}_{4}$ bed and stored at $-20^{\circ} \mathrm{C}$ in a closed amber glass vial. Essential oil yield was calculated in milliliters of oil per $100 \mathrm{~g}$ of fresh parsley (Camilotti et al., 2015).

\section{Chemical identification of essential oil by gas chromatographic-mass spectrometric analysis}

Gas chromatographic-mass spectrometric analysis (EI) was performed using an Agilent 5973 Network chromatographer coupled to an Agilent 5973 MSD mass spectrometer (Agilent Technologies, Santa Clara, CA, USA). The separation was achieved using an Agilent 19091S-433 HP-5MS fused silica capillary column, 30 x $0.25 \mathrm{~mm}$ i.d., $0.25-\mu \mathrm{m}$ film thickness. The gas chromatographic oven temperature was programmed from $60^{\circ}$ to $285^{\circ} \mathrm{C}$ at a rate of $4.3^{\circ} \mathrm{C} / \mathrm{min}$. Helium was used as the carrier gas. The inlet pressure was $25 \mathrm{kPa}$ and the linear velocity was $1 \mathrm{~mL} / \mathrm{min}$ at $210^{\circ} \mathrm{C}$. The injector temperature was $250^{\circ} \mathrm{C}$ and the injection mode was splitless. The mass spectrometric scan conditions were as follows: source temperature, $200^{\circ} \mathrm{C}$; interface temperature, $250^{\circ} \mathrm{C}$; energy, $70 \mathrm{eV}$; and mass scan range, 40 350 amu (Tešević et al., 2009).

\section{Antibacterial activity}

The following bacteria were used: Bacillus cereus Frankland and Frankland, 1887 (clinical isolate), E. cloacae (Jordan, 1890) Hormaeche and Edwards, 1960 (clinical isolate), E. coli (Migula) Castellani and Chalmers (ATCC 35218), L. monocytogenes (Murray et al.) Pirie (NCTC 7973), P. aeruginosa (Schroeter) Migula (ATCC 27853), S. enterica subsp enterica (ex Kauffmann and Edwards) Le Minor and Popoff serovar Typhimurium (ATCC 13311), and Staphylococcus aureus subsp aureus Rosenbach (ATCC 6538). All microorganisms used in this study were obtained from the Culture Collection of the Mycological Laboratory, Department of Plant Physiology, Institute for Biological Research 'Siniša Stanković', Belgrade, Serbia. The antibacterial assay was performed using the microdilution method (CLSI, 2009; Tsukatani et al., 2012). The bacterial suspensions were adjusted with sterile saline to a concentration of $1.0 \times 10^{5} \mathrm{CFU} / \mathrm{mL}$. The inocula were prepared daily and stored at $4^{\circ} \mathrm{C}$. Dilutions of inocula were cultured to check the validity of the inoculum.

Genetics and Molecular Research 15 (3): gmr.15038538 
Essential oil was dissolved in dimethyl sulfoxide $(50 \mathrm{mg} / \mathrm{mL})$ and Tween $80(1 \mathrm{mg} /$ $\mathrm{mL}$ ), and added to $100 \mu \mathrm{L}$ tryptic soy broth (TSB) culture medium with a bacterial inoculum of $1.0 \times 10^{4} \mathrm{CFU}$ per well. The minimum inhibitory concentration (MIC) obtained from the susceptibility test (Espinel-Ingroff, 2001) was also determined by the colorimetric microbial viability assay based on the reduction of INT ( $p$-iodonitrotetrazolium violet) [2-(4-iodophenyl)3-(4-nitrophenyl)-5-phenyltetrazolium chloride; Sigma] color and compared with positive controls for each bacterial strain (Janaćković et al., 2015). The minimum bactericidal concentration (MBC) was determined by $2 \mu \mathrm{L}$ serial sub-cultivation into microtiter plates containing $100 \mu \mathrm{L}$ TSB per well and further incubation for $24 \mathrm{~h}$. The lowest concentration without growth was defined as the $\mathrm{MBC}$, indicating $99.5 \%$ killing of the original inoculum. The optical density of each well was measured at $655 \mathrm{~nm}$ by a Microplate Manager 4.0 (BioRad Laboratories) and was compared with a blank control and positive controls. Streptomycin $\left(\right.$ Sigma $^{\mathrm{TM}}$ P7794) and ampicillin (Panpharma $\left.{ }^{\mathrm{TM}}\right)$ were used as positive controls $(1 \mathrm{mg} / \mathrm{mL}$ in sterile physiological saline). A solution of dimethyl sulfoxide $(50 \mathrm{mg} / \mathrm{mL})$ was used as a negative control.

\section{Antifungal activity}

For the antifungal bioassays, eight fungal species were used: Aspergillus fumigatus Fresenius (ATCC 1022), Aspergillus niger van Tieghem (ATCC 6275), Aspergillus ochraceus Wilhelm (ATCC 12066), Aspergillus versicolor (Vuillemin) Tiraboschi (ATCC 11730), Penicillium funiculosum Thom (ATCC 8725), Penicillium ochrochloron Biourge (ATCC 9112), Penicillium verrucosum var. cyclopium (Westling) Samson, Stolk \& Hadlok (food isolate), and Trichoderma viride Pers. (IAM 5061). Fungi were maintained on malt agar medium culture, stored at $4^{\circ} \mathrm{C}$, and sub-cultured once a month. In order to investigate antifungal activity, a modified microdilution technique was used (Espinel-Ingroff, 2001; Janaćković et al., 2015). Fungal spores were washed from the agar plate surface with sterile saline solution $(8.5 \mathrm{mg} / \mathrm{mL})$ containing Tween $80(1 \mathrm{mg} / \mathrm{mL})$. A spore suspension was adjusted with sterile saline to a concentration of $1.0 \times 10^{5}$ spores $/ \mathrm{mL}$ and stored at $4{ }^{\circ} \mathrm{C}$ as inoculum for further use. Dilutions of inocula were cultured on solid malt agar to check inoculum validity. MIC determination was performed utilizing a serial dilution technique with 96-well microtiter plates and a solution containing dimethyl sulfoxide $(50 \mathrm{mg} / \mathrm{mL})$ with Tween $80(10 \mathrm{mg} / \mathrm{mL})$ added to broth malt (BM) culture medium with inoculum. Microplates were incubated on a rotary shaker $(160 \mathrm{rpm})$ for $72 \mathrm{~h}$ at $28^{\circ} \mathrm{C}$. The lowest concentrations without visible microbial growth in an optical microscope were defined as the MIC. Minimum fungicidal concentration (MFC) was determined by serial sub-cultivation of $2 \mu \mathrm{L}$ of tested compounds dissolved in $\mathrm{BM}$ inoculated for $72 \mathrm{~h}$ into microtiter plates containing $100 \mu \mathrm{L}$ BM per well and incubated at $28^{\circ} \mathrm{C}$ for $72 \mathrm{~h}$. The lowest concentration with no microbial visible growth was defined as the MFC, indicating $99.5 \%$ killing of the original inoculum. A solution of dimethyl sulfoxide (50 $\mathrm{mg} / \mathrm{mL}$ ) was used as a negative control and the commercial fungicides bifonazole (Srbolek ${ }^{\mathrm{TM}}$ ) and ketoconazole (Zorkapharma ${ }^{\mathrm{TM}}$ ) were used as positive controls $(1-3500 \mu \mathrm{g} / \mathrm{mL})$.

\section{Statistical analysis}

Three samples from each microbial strain were used, and every assay was carried out three times. The results are reported as the average and standard deviation. A comparison 
among treatments for the same microbial strain was performed by the Tukey test $(\mathrm{P} \leq 0.05)$ using the SPSS v. 18.0 program.

\section{RESULTS}

Parsley essential oil yield was $0.2 \%$ and thirty compounds were identified consisting of $100.0 \%$ of volatile constituents (Table 1$)$. Major compounds were apiol $(50.3 \%)$, myristicin (14.0\%), both phenylpropanoids, and $\beta$-phellandrene (14.6\%), a terpenoid (Table 1).

Table 1. Identification of the chemical composition of Petroselinum crispum essential oil based on retention index (RI) and on comparison of mass spectra methods.

\begin{tabular}{|c|c|c|c|}
\hline Peak & Compound* & RI & Composition (\%) \\
\hline 1 & n.i. & 845 & 0.2 \\
\hline 2 & $\alpha$-Pinene & 913 & 2.1 \\
\hline 3 & $\beta$-Pinene & 967 & 1.3 \\
\hline 4 & Myrcene & 984 & 4.4 \\
\hline 5 & $\alpha$-Phellandrene & 1002 & 0.1 \\
\hline 6 & $\rho$-Cymene & 1017 & 0.4 \\
\hline 7 & $\beta$-Phellandrene & 1023 & 14.6 \\
\hline 8 & Terpinolene & 1075 & 1.5 \\
\hline 9 & meta-Cymenene & 1077 & 1.9 \\
\hline 10 & Cryptone & 1183 & 1.6 \\
\hline 11 & $\beta$-Cyclocitral & 1224 & 0.5 \\
\hline 12 & n.i. & 1383 & 0.4 \\
\hline 13 & $\beta$-Elemene & 1389 & 1.4 \\
\hline 14 & n.i. & 1392 & 1.0 \\
\hline 15 & (E-)Caryophyllene & 1412 & 0.3 \\
\hline 16 & n.i. & 1466 & 0.3 \\
\hline 17 & Germacrene D & 1480 & 0.4 \\
\hline 18 & $\alpha$-Selinene & 1494 & 0.2 \\
\hline 19 & Germacrene A & 1506 & 0.8 \\
\hline 20 & Myristicin & 1518 & 14.0 \\
\hline 21 & Carotol & 1580 & 0.3 \\
\hline 22 & n.i. & 1638 & 0.1 \\
\hline 23 & Selin-11-en-4 $\alpha$-ol & 1651 & 0.2 \\
\hline 24 & Apiol & 1684 & 50.3 \\
\hline 25 & n.i. & 1707 & 0.3 \\
\hline 26 & n.i. & 1721 & 0.3 \\
\hline 27 & n.i. & 1722 & 0.1 \\
\hline 28 & n.i. & 1779 & 0.4 \\
\hline 29 & n.i. & 1836 & 0.4 \\
\hline 30 & n.i. & 1935 & 0.2 \\
\hline \multicolumn{3}{|l|}{ Total } & 100.0 \\
\hline \multicolumn{4}{|c|}{ Compound groups (\%) } \\
\hline \multicolumn{3}{|c|}{ Monoterpene hydrocarbons } & 26.50 \\
\hline \multicolumn{3}{|c|}{ Oxygenated monoterpenes } & 0.90 \\
\hline \multicolumn{3}{|c|}{ Sesquiterpene hydrocarbons } & 4.40 \\
\hline \multicolumn{3}{|c|}{ Oxygenated sesquiterpenes } & 0.30 \\
\hline \multicolumn{3}{|c|}{ Phenylpropanoids } & 64.40 \\
\hline
\end{tabular}

*Compound listed in order of elution from a HP-5MS column; n.i. = unidentified compound.

Parsley essential oil inhibited the growth of all bacteria with MICs ranging from 0.04 to $1.00 \mathrm{mg} / \mathrm{mL}$ (Figure 1). Parsley essential oil showed bacteriostatic activity at lower concentrations than at least one of the controls against $L$. monocytogenes, $S$. enterica, and $S$. aureus (Figure 1). The essential oil killed all bacteria with MBCs ranging from 0.15 to 10.00 $\mathrm{mg} / \mathrm{mL}$ (Figure 2). The most resistant bacteria were E. cloacae and E. coli with MBC values of 
$10.00 \mathrm{mg} / \mathrm{mL}$ (Figure 2). The most susceptible bacteria were P. aeruginosa, S. enterica, and $S$. aureus (Figure 2). The MBC value of essential oil against $S$. aureus was similar to ampicillin and 1.7 times lower than streptomycin (Figure 2).

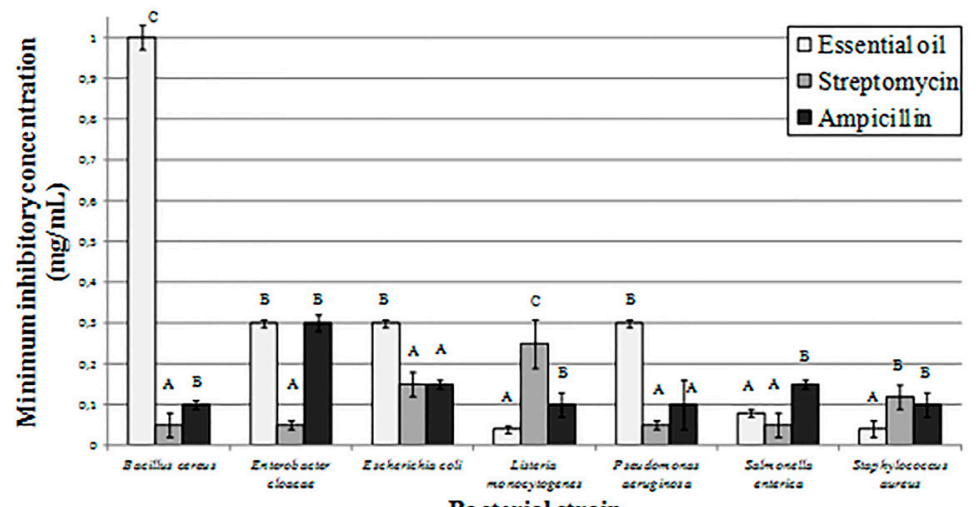

Bacterial strain

Figure 1. Minimum inhibitory concentration of Petroselinum crispum essential oil, streptomycin, and ampicillin on bacterial strains. Different letters above bars indicate statistically significant differences only among the treatments performed for each bacterial strain according to the Tukey test $(\mathrm{P} \leq 0.05)$.

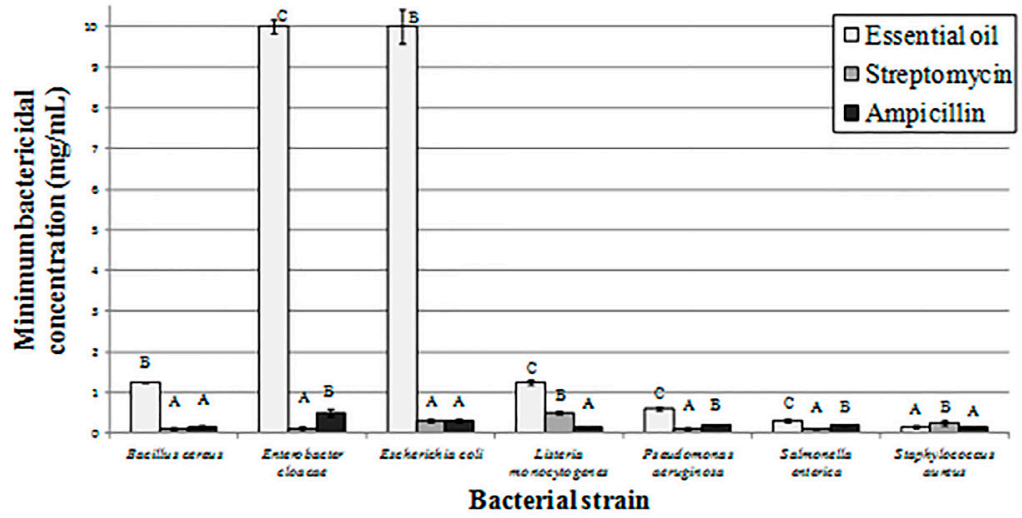

Figure 2. Minimum bactericidal concentration of Petroselinum crispum essential oil, streptomycin, and ampicillin of bacterial strains. Different letters above bars indicate statistically significant differences only among the treatments performed for each bacterial strain according to the Tukey test $(\mathrm{P} \leq 0.05)$.

Parsley essential oils showed fungistatic activity against all fungi, mainly $P$. ochrochloron and T. viride (Figure 3). P. ochrochloron and T. viride had MIC values at low concentrations of essential oil compared with the ketoconazole control (Figure 3). For the fungicidal activity, parsley essential oil was effective against all fungi, mainly P. funiculosum and T. viride, with MFCs of 1.25 and $2.50 \mathrm{mg} / \mathrm{mL}$, respectively (Figure 4). However, in general, fungicidal concentrations of the essential oil ranged from 5 to 62.5 times higher than the controls (Figure 4).

Genetics and Molecular Research 15 (3): gmr.15038538 


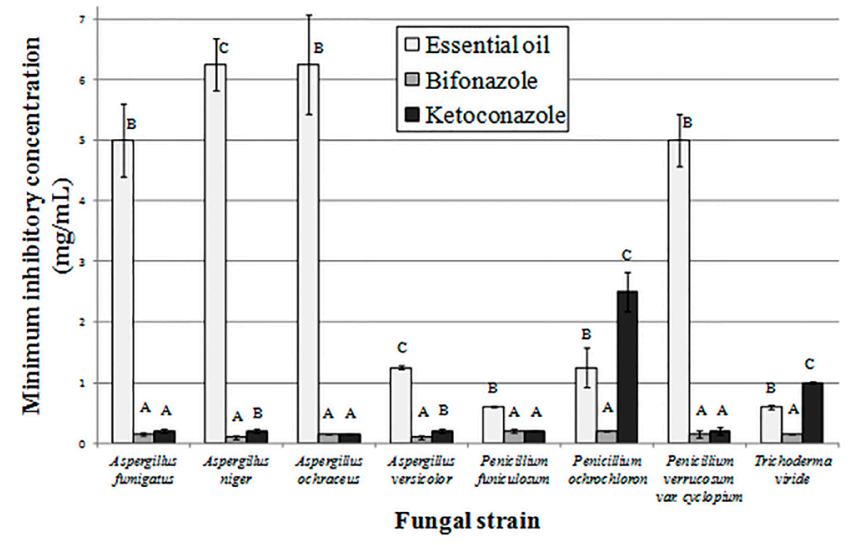

Figure 3. Minimum inhibitory concentration of Petroselinum crispum essential oil, bifonazole, and ketoconazole of fungal strains. Different letters above bars indicate statistically significant differences only among the treatments performed for each fungal strain according to the Tukey test $(\mathrm{P} \leq 0.05)$.

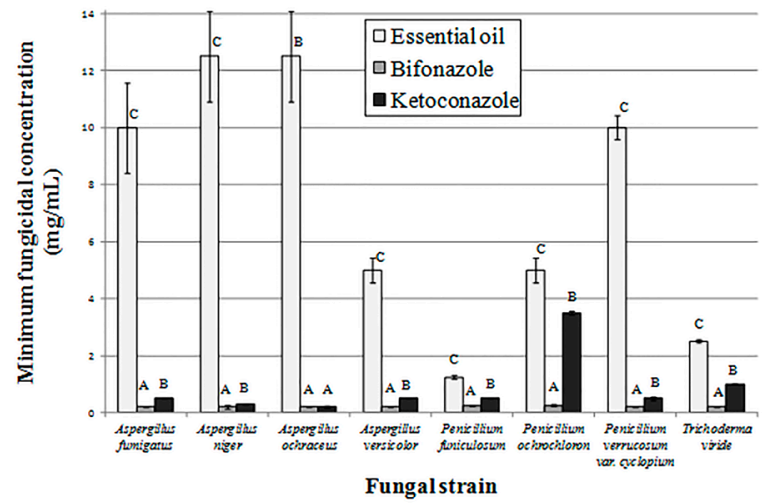

Figure 4. Minimum fungal concentration of Petroselinum crispum essential oil, bifonazole, and ketoconazole of fungal strains. Different letters above bars indicate statistically significant differences only among the treatments performed for each fungal strain according to the Tukey test $(\mathrm{P} \leq 0.05)$.

\section{DISCUSSION}

The yield of parsley essential oil obtained from aerial parts ranges from 0.03 to $3.2 \%$ (Petropoulos et al., 2009; Viuda-Martos et al., 2011; Vokk et al., 2011). These results indicate a great variation for this species, and that our findings were within the normal range. The major compounds reported for parsley essential oil obtained from aerial parts, except seeds, vary widely in quantity and composition worldwide (Table 2). Our results showed apiol (50.3\%), myristicin (14.0\%), and $\beta$-phellandrene (14.6\%) in Brazil. This diverse chemical variation could be related to genetic and environmental factors affecting the secondary metabolism of this species, harvesting time of the biological material in different development stages, interaction with microorganisms and insects, and different post-harvest techniques, as suggested by Morais and Castanha (2012) and Camilotti et al. (2015). Although there are 
variations in the major compounds of parsley essential oil worldwide, apiol and/or myristicin have always been among the major constituents.

Table 2. Major compounds reported for parsley essential oil obtained from aerial parts, except seeds.

\begin{tabular}{l|c|c|c|c|c|c|c|c|l}
\hline Country & \multicolumn{7}{|c|}{ Major chemical compounds (\%) } & \multirow{2}{*}{ Reference } \\
\cline { 2 - 11 } & Apiol & Myristicin & $\begin{array}{c}p \text {-mentha-1,3,8- } \\
\text { triene }\end{array}$ & Sabinene & $\alpha$-pinene & $\beta$-phellandrene & $\beta$-pinene & $\begin{array}{c}\text { 1-allyl-2,3,4,5- } \\
\text { tetramethoxy- } \\
\text { benzene }\end{array}$ & \\
\hline Brazil & 41.0 & 5.1 & - & - & - & - & - & - & Camilotti et al. (2015) \\
\hline China & 17.5 & 32.8 & - & - & 16.6 & - & 11.5 & 10.0 & Zhang et al. (2006) \\
\hline Egypt & 46.5 & - & - & - & 22.2 & - & 16.1 & - & Viuda-Martos et al. (2011) \\
\hline Greece & - & $0.1-27.7$ & - & - & - & $26.7-40.3$ & - & - & Petropoulos et al. (2009) \\
\hline Lebanon & 7.6 & - & 8.2 & 21.1 & - & - & - & - & Knio et al. (2008) \\
\hline Spain & 34.3 & 11.2 & 13.3 & - & - & 21.9 & - & - & Díaz-Maroto et al. (2002) \\
\hline
\end{tabular}

There are few reports on the antibacterial activity of parsley essential oil obtained from aerial parts, except seeds. Viuda-Martos et al. (2011), using the disc diffusion method, reported that essential oil of parsley aerial parts (without seeds) had no antibacterial activity against Listeria innocua, Serratia marcescens, and Pseudomonas fluorescens. Gutierrez et al. (2008), using a microtitre plate test, reported no antibacterial activity of commercial parsley essential oil against Enterobacter aerogenes, E. cloacae, E. coli, P. aeruginosa, $P$. fluorescens, Pseudomonas putida, S. enterica, B. cereus, Lactobacillus brevis, Lactobacillus plantarum, and $S$. aureus. Teixeira et al. (2013), using the disc diffusion method, reported no antibacterial activity of commercial essential oil from parsley aerial parts, without seeds, on $E$. coli, P. putida, and S. enterica, but bacteriostatic activity against Brochothrix thermosphacta, L. innocua, L. monocytogenes, and Shewanella putrefaciens. Hogg (2005) suggested that resistance of Gram-negative bacteria could be due to the complexity of their double layer cell membrane in comparison with the single membrane of Gram-positive bacteria. Our study partially agrees with Hogg as the most resistant bacteria to parsley essential oil were two Gram-negative bacteria: E. cloacae and E. coli (Figure 2). However, Gram-negative bacteria such as $P$. aeruginosa and $S$. enterica were susceptible as well as Gram-positive bacteria such as B. cereus, L. monocytogenes, and S. aureus (Figure 2). On the other hand, these different results regarding antibacterial activity among different authors could be related to distinct composition of the essential oil. In regards to Teixeira et al. (2013), the parsley essential oil composition was different from our results in which the main compounds were 4-methoxy6-(2-propenyl)-1,3-benzodioxole (45.1\%), 1,2,3,4-tetramethoxy-5-(2-propenyl)-benzene $(16.9 \%)$, and apiol (29.9\%), and this variation could have affected the antimicrobial activity. Thus, the industrial food production methods for natural plant extracts should control for biotic and abiotic factors in order to avoid variation in the essential oil composition.

The antimicrobial methods could also affect MIC and MBC values. The disc diffusion test used by Teixeira et al. (2013) and Viuda-Martos et al. (2011) is simple, convenient, and has been well-standardized but presents qualitative results and approximate MIC values (Jorgensen and Ferraro, 2009). In our study, a microdilution test, a quantitative test that allows for higher accuracy and reproducibility, was used to determine MIC and MBC values (Jorgensen and Ferraro, 2009). The parsley essential oil in our study showed high bactericidal activity mostly against $P$. aeruginosa, $S$. enterica, and $S$. aureus. These bacteria are common food pathogens and produce a wide variety of toxins (Al-Qurainy et al., 2013). S. aureus - for instance - is heat resistant, can live at low $\mathrm{pH}$ with activity in the digestive tract after ingestion,

Genetics and Molecular Research 15 (3): gmr.15038538 
and is a common cause of skin infection and food poisoning (Evenson et al., 1988; AlQurainy et al., 2013). Thus, parsley essential oil could be an alternative to control these bacteria. Furthermore, several bacteria are becoming resistant to methicillin, which is a new challenge for the food industry (Martin et al., 2014). In our study, the antibacterial activity of parsley essential oil - a plant that is widely used as fresh green sprigs to garnish and aromatize foods - could be an alternative to control bacteria during food processing, storage, and/or packing. Moreover, according to Al-Qurainy et al. (2013), the use of crude plant extracts and essential oils can be used to reduce the use of synthetic chemical compounds in the preservation of foodstuff. Synthetic food preservatives are effective and inexpensive, but they can be also toxic for animals, the environment, and increase microorganism resistance (Aarestrup, 2000).

The lowest essential oil concentration with fungistatic and fungicidal activities was against $P$. funiculosum and $T$. viride. These fungi are common causal agents of foodborne diseases, food spoilage, and opportunistic pathogens. In addition, T. viride is the most common contaminant in mushroom cultivation (Burt, 2004). It can grow on compost and/or the casing layer, contaminating mushroom production and result in enormous losses. In order to maintain mushroom yield, fungicides such as benomyl $\left(\right.$ Benlate $^{\circledR}$ ) and prochloraz (Sporgon ${ }^{\circledR}$ ) are used. However, it has been suggested that they cause carcinogenic side effects (Soković and Van Griensven, 2006). Thus, parsley essential oil could be an alternative to control fungal contamination or diseases as a result of green mold in mushroom cultivation. In addition to its beneficial culinary and medicinal uses, this report demonstrates the potential use of $P$. crispum as an antimicrobial agent. Other studies on the use and application of parsley essential oil on a larger scale are encouraged.

\section{CONCLUSIONS}

A parsley essential oil yield of $0.2 \%$ has antibacterial and antifungal activities. The major compounds of the essential oil are apiol and myristicin, both phenylpropanoids, and $\beta$-phellandrene, a terpenoid. P. crispum essential oil had bacteriostatic activity against all tested bacteria, mainly $S$. aureus, L. monocytogenes, and $S$. enterica, at similar or lower concentrations than streptomycin or ampicillin. Bactericidal activity was effective against all tested bacteria, mainly $S$. aureus, at similar or lower concentrations than streptomycin or ampicillin. This essential oil also had fungistatic activity against all tested fungi, mainly $P$. ochrochloron and $T$. viride, at lower concentrations than the ketoconazole control. Fungicidal activity of the essential oil was effective for all tested fungi but requires a higher concentration than the one used for the bifonazole and ketoconazole controls. Considering the culinary and medicinal properties of parsley, this report expands its importance as an alternative antimicrobial agent.

\section{ACKNOWLEDGMENTS}

The authors thank Universidade Paranaense, the Postgraduate Program in Biotechnology Applied to Agriculture of the Universidade Paranaense in Brazil, Coordenação de Aperfeiçoamento de Pessoal de Nível Superior (CAPES), and the Ministry of Education, Science and Technological Development of Serbia (grant \#173032).

Genetics and Molecular Research 15 (3): gmr.15038538 


\section{REFERENCES}

Aarestrup FM (2000). Occurrence, selection and spread of resistance to antimicrobial agents used for growth promotion for food animals in Denmark. APMIS (Suppl. 101): 1-48.

Addis M and Sisay D (2015). A review on major food borne bacterial illnesses. J. Trop. Dis 3: 1000176 10.4176/2329891X.1000176.

Al-Qurainy F, Z Gaafar AR, Khan S, Nadeem M, et al. (2013). Antibacterial activity of leaf extract of Breonadia salicina (Rubiaceae), an endangered medicinal plant of Saudi Arabia. Genet. Mol. Res. 12: 3212-3219. http://dx.doi. org/10.4238/2013.August.29.5

Bjarnsholt T, Jensen PØ, Jakobsen TH, Phipps R, et al.; Scandinavian Cystic Fibrosis Study Consortium (2010). Quorum sensing and virulence of Pseudomonas aeruginosa during lung infection of cystic fibrosis patients. PLoS One 5: e10115. http://dx.doi.org/10.1371/journal.pone.0010115

Burt S (2004). Essential oils: their antibacterial properties and potential applications in foods--a review. Int. J. Food Microbiol. 94: 223-253. http://dx.doi.org/10.1016/j.ijfoodmicro.2004.03.022

Camilotti J, Ferarrese L, Bortolucci WC, Gonçalves JE, et al. (2015). Essential oil of parsley and fractions to in vitro control of cattle ticks and dengue mosquitoes. J. Med. Plants Res. 9: 1021-1030. http://dx.doi.org/10.5897/JMPR2015.5941

CLSI. (2009). Clinical and laboratory standards institute methods for dilution antimicrobial susceptibility tests for bacteria that grow aerobically. 8th edn. Available at [http://pt.scribd.com/doc/89642226/CSLI-2009]. Accessed February 4, 2016.

Díaz-Maroto M, Pérez-Coello M and Cabezudo M (2002). Effect of different drying methods on the volatile components of parsley (Petroselinum crispum L.). Eur. Food Res. Technol. 215: 227-230. http://dx.doi.org/10.1007/s00217-002$\underline{0529-7}$

Ding T, Jiang T, Zhou J, Xu L, et al. (2010). Evaluation of antimicrobial activity of endophytic fungi from Camptotheca acuminata (Nyssaceae). Genet. Mol. Res. 9: 2104-2112. http://dx.doi.org/10.4238/vol9-4gmr809

Espinel-Ingroff A (2001). Comparison of the E-test with the NCCLS M38-P method for antifungal susceptibility testing of common and emerging pathogenic filamentous fungi. J. Clin. Microbiol. 39: 1360-1367. http://dx.doi.org/10.1128/ JCM.39.4.1360-1367.2001

Evenson ML, Hinds MW, Bernstein RS and Bergdoll MS (1988). Estimation of human dose of staphylococcal enterotoxin A from a large outbreak of staphylococcal food poisoning involving chocolate milk. Int. J. Food Microbiol. 7: 311316. http://dx.doi.org/10.1016/0168-1605(88)90057-8

Glamočlija J, Soković M, Tešević V, Linde GA, et al. (2011). Chemical characterization of Lippia alba essential oil: an alternative to control green molds. Braz. J. Microbiol. 42: 1537-1546.

Gutierrez J, Rodriguez G, Barry-Ryan C and Bourke P (2008). Efficacy of plant essential oils against foodborne pathogens and spoilage bacteria associated with ready-to-eat vegetables: antimicrobial and sensory screening. J. Food Prot. 71: 1846-1854.

Hogg S (2005). Essential microbiology. 1st ed. John Wiley \& Sons, Chichester, West Sussex, England.

Iglewski BH (1996). Pseudomonas. In: Medical microbiology (Baron S et al., eds.). 4th edn. University of Texas Medical Branch at Galveston, Galveston.

Janaćković P, Novaković J, Soković M, Vujisić L, et al. (2015). Composition and antimicrobial activity of essential oils of Artemisia judaica, A. herba-alba and A. arborescens from Libya. Arch. Biol. Sci. 67: 455-466. http://dx.doi. org/10.2298/ABS141203010J

Jorgensen JH and Ferraro MJ (2009). Antimicrobial susceptibility testing: a review of general principles and contemporary practices. Clin. Infect. Dis. 49: 1749-1755. http://dx.doi.org/10.1086/647952

Knio KM, Usta J, Dagher S, Zournajian H, et al. (2008). Larvicidal activity of essential oils extracted from commonly used herbs in Lebanon against the seaside mosquito, Ochlerotatus caspius. Bioresour. Technol. 99: 763-768. http:// dx.doi.org/10.1016/j.biortech.2007.01.026

Martin E, Lina G and Dumitrescu O (2014). Staphylococcus | Staphylococcus aureus. In: Encyclopedia of Food Microbiology. (Batt CA and Tortorello ML, eds.). Academic press, London, 501-507.

McCarroll NE, Protzel A, Ioannou Y, Frank Stack HF, et al. (2002). A survey of EPA/OPP and open literature on selected pesticide chemicals. III. Mutagenicity and carcinogenicity of benomyl and carbendazim. Mutat. Res. 512: 1-35. http://dx.doi.org/10.1016/S1383-5742(02)00026-1

Mead PS, Slutsker L, Dietz V, McCaig LF, et al. (1999). Food-related illness and death in the United States. Emerg. Infect. Dis. 5: 607-625. http://dx.doi.org/10.3201/eid0505.990502

Morais LAS and Castanha RF (2012). Chemical composition of sweet basil essential oil naturally submitted to Planococcus citri infestation. Hortic. Bras. 30: S2178-S2182.

Genetics and Molecular Research 15 (3): gmr.15038538 
Petropoulos SA, Daferera D, Polissiu G and Passam HC (2009). Effect nitrogen-application rate on the biomass, concentration, and composition of essential oils in the leaves and roots of three types of parsley. J. Plant Nutr. Soil Sci. 172: 210-215. http://dx.doi.org/10.1002/jpln.200700311

Soković M and Van Griensven LJLD (2006). Antimicrobial activity of essential oils and their components against the three major pathogens of the cultivated button mushroom, Agaricus bisporus. Eur. J. Plant Pathol. 116: 211-224. http://dx.doi.org/10.1007/s10658-006-9053-0

Soković M, Ćirić A, Glamočlija J, Nikolić M, et al. (2014). Agaricus blazei hot water extract shows anti quorum sensing activity in the nosocomial human pathogen Pseudomonas aeruginosa. Molecules 19: 4189-4199. http://dx.doi. org/10.3390/molecules19044189

Teixeira B, Marques A, Ramos C, Neng NR, et al. (2013). Chemical composition and antibacterial and antioxidant properties of commercial essential oils. Ind. Crops Prod. 43: 587-595. http://dx.doi.org/10.1016/j.indcrop.2012.07.069

Tešević V, Milosavljević S, Vajs V, Đorđević I, et al. (2009). Chemical composition and antifungal activity of the essential oil of Douglas fir (Pseudosuga menziesii Mirb. Franco) from Serbia. J. Serb. Chem. Soc. 74: 1035-1040. http:// dx.doi.org/10.2298/JSC0910035T

Tsukatani T, Suenaga H, Shiga M, Noguchi K, et al. (2012). Comparison of the WST-8 colorimetric method and the CLSI broth microdilution method for susceptibility testing against drug-resistant bacteria. J. Microbiol. Methods 90: 160166. http://dx.doi.org/10.1016/j.mimet.2012.05.001

Viuda-Martos M, Mohamady MA, Fernández-López J, Abd ElRazik KA, et al. (2011). In vitro antioxidant and antibacterial activities of essentials oils obtained from Egyptian aromatic plants. Food Contr. 22: 1715-1722. http:// dx.doi.org/10.1016/j.foodcont.2011.04.003

Vokk R, Lõugas T, Mets K and Kravets M (2011). Dill (Anethum graveolens L.) and parsley (Petroselinum crispum (Mill.) Fuss) from Estonia: seasonal differences in essential oil composition. Agron. Res 9: 515-520.

Zhang H, Chen F, Wang X and Yao HY (2006). Evaluation of antioxidant activity of parsley (Petroselinum crispum) essential oil and identification of its antioxidant constituents. Food Res. Int. 39: 833-839. http://dx.doi.org/10.1016/j. foodres.2006.03.007

Genetics and Molecular Research 15 (3): gmr.15038538 